\title{
nglish or Chinese Pheasants, Rearing Them in Missouri.
}

SOME SUGGESTIONS TO THOSE WHO HAVE SECURED BIRDS FOR SCIENTIFIC AND PROPAGATING PURPOSES, FROM THE MISSOURI STATE GAME FARM AT JEFFERSON CITY, MO.

\author{
JESSE A., TOLERTON, \\ State Game and Fish Commissioner. \\ JEFFERSON, CITY, MO.
}




late, and the supply being limited, for me to reserve all future birds now possible to be obtained, for the State Game Farm. The State will have produced a generous supply by this fall for distribution to individuals and for liberation in the most suitable places. It is intended to reserve a considerable number of birds for each part of Missouri in the fall distribution. With this explanation, it is hoped that this pamphlet will be accepted, instead of a personal reply to the generous flood of letters now being received at this department, from all parts of the State. This correspondence is most gratifying to me as an indication that my fellow citizens believe I am trying to do the best I can to carry out their wishes.

Yours rery truly,

JESSE A. TOLERTON,

State Game and Fish Commissioner.

\section{CARE OF ENGLISH AND CHINESE PHEASANTS.}

The supply of pheasants and partridges which can be obtained is very limited. In sending birds to private individuals, for breeding purposes, they will appreciate the need of taking most exacting pains in studying the conditions which will produce the largest increase. The first thing to remember is, that wild creatures in confinement must have the conditions in captivity as nearly as possible to those found in the wild state. The prime importance, above all others, is cleanliness, in the minutest detail, suitable food, fresh water, and ample range, is the next consideration. As the pheasants will lay from 40 to 100 eggs in a season, domestic hens, preferably cochin bantams, Plymouth Rocks, Silver or Golden Wyandottes, should be selected to hatch them. The hens should not have large feet, neither should those having seales or sores on their feet or body be used. Hens with foul smelling breath should be avoided as a plague. Neat, clean, healthy hens should be secured, and these should be treated with insect powder, especially under the wings and the root of the tail. Sickness and vermin should not be transmitted to the newly born pheasants upon their arrival in this world. There does not seem to be any considerable trouble about the care of the old pheasants in their laying of eggs or their hatching; the main difficulty comes with raising the young chicks. This trouble is largely caused from acquiring disease from other poultry and from improper food. Nearly all birds, like human beings, require different food for their young, in that food used for adults cannot be assimilated by the young.

The pheasants in captivity, will drop their eggs anywhere on the ground, and they will eat them unless gathered promptly. The eggs should be carefully put aside, packed over in bran. Oats draw the moisture from the eggs, and should not be used. These eggs should be 
gently turned over every three days, and can be kept three weeks. Fresh eggs hatch best. About eighteen or twenty eggs, according to the size of the hen, can be used in a "setting." In a big hatchery farm, the hens are first allowed to set on glass eggs for three days to get used to the nest and the handling. The nest should be a ventilated box, with a lid to it, but no bottom. Inside the box there should be about four inches of dry sod, stamped solid, but having a hollow for the nest in the center. This keeps the nest higher and dryer than the surrounding ground. A small quantity of hay or straw can be used to line the nest. The hen cannot get off the nest, unless taken out by opening the lid, and allowed to run about in a wire screened inclosure in front of the nest. This should be about three feet square, with about half of the screened enclosure covered by a roof for a shelter. The hen is fed boiled corn, or other grains with plenty of gravel, once a day, and given pure clean water. In about fifteen minutes she should be put back on the nest and closed in. In about twenty-three days the eggs will hatch. The young chicks should be kept in a basket or box lined with cloth, and not to be immediately carried out into the cold or in drafts of air. The nesting boxes should be comfortably located for the setting hen, as well as for the young birds. The inclosed wire run should be further guarded by an outside wire fence, with traps set about it to catch house cats, coons, possums, weasels, mink, skunk, or other animals which will come to get the young chicks. A tall pole should be set in the ground where it is convenient for hawks to light on it. On top should be a spring trap for the hawks to light upon and get caught. Hawks are very bothersome.

The chicks require no food during the first 24 hours, but later must be fed upon hard boiled eggs, mixed with Spratts Pheasant meal, worked up with barley meal and screened through a sieve. They should be fed every four hours; at six o'clock, ten, two and six for the first three weeks, afterwards three times daily is sufficient. At six or seven weeks old, twice a day will do. After the third day, the rearing coop and its screened inclosure about it, should be moved to new ground, every day until the birds are well developed. Even the old birds cannot long remain upon the same ground. Sickness in pheasants is generally caused by filth, improper food and poor housing. They are a cleanly bird when wild. Young chicks will eat and relish egg and milk custard mixed in their food. Lettuce and cabbage leaves are also desirable feed. Chopped young onions will also improve their food mixtures. A small quantity of grain can advantageously be left about the coop to permit the birds to gradually adopt more of a grain diet. The mother hen should constantly be kept free from lice by using insect powder. After 14 to 17 days have elapsed, the pheasant raiser can constantly keep adding to the feed, boiled rice, barley meal, corn meal, flax meal, dairi seed, wheat, hemp seed, increasing the diet up to cracked corn. At this time, the birds should be fed on coarser feed, the breeder should then watch for diseases, such as gaps, roop and scowes. When eight or ten weeks old they will leave the mother and look for roosting quarters. They frequent the open fields during the day and retreat toward the 
woods in the evening, roosting in a pine or oak tree at night. In their wild state, they can stand the most rigorous weather. They are a game bird, par excellence, and it is questionable whether any other bird excels it in game or food qualities, certainly not in beauty.

It is rank foolishness to hunt them without a dog, as they can conceal themselves in the scantest cover. When running in cover, they run rapidly like California quail and can pass through short or tall grass without hardly moving the top of it. They lie well to the dog and are swift and strong on the wing. They do not succumb to slight gunshot wounds, and when wounded will tax the skill of the best retriever.

In Oregon, where originally only 50 pair were liberated in 1882, they are most abundant. It is said that 30,000 were killed in a single county alone. They were protected for seven years, and thereafter the open season was six weeks, reduced later to thirty days on male birds only. They are great egg producers, and often raise two or even three broods in their wild state. When the season is open they are a most wary fowl. When the season has closed they will venture into barnyards and eat with the domestic fowl, though always very suspicious and watchful. Anyone who can raise turkeys, should be able to raise English or Chinese pheasants. The birds soon learn to know their keeper, and should not be bothered by visitors, who cause them great excitement in the attempt to fly against the screens.

The pheasant pens cannot be too large. A cock and two or three hens should have a pen not less than 10 by 12 feet. One cock and a hen are said to produce most fertile eggs, thongh nearly all pheasant eggs are fertile.

\section{WRITE FOR INFORMATION.}

Letters written to this department, inquiring about the care of English or Chinese pheasants will receive a prompt reply, and no one should wait until the last minute if any pheasant sickness or other trouble arises, as this department greatly desires that private pheasantries in Missouri shall be successful aids in helping the State Game and Fish Department to stock the State.

\section{ABOUT HUNGARIAN PARTRIDGES.}

Hungarian partridges should be liberated as soon as received, as they cannot be raised in confinement. They must be allowed to reproduce in nature's own way, and they will not even mate in captivity.

\section{A SAMPLE LETTER.}

It would afford me much pleasure to reproduce some of the letters received at this office. Many of the correspondents show unmistakably the deep interest which is manifested in the subject of State propagation of game birds. The following communication will convey an idea of the general trend of thought on this interesting and beneficial subject: 
Sedalia, Mo., March 1st, 1910.

Mr. Jesse Tolerton, State Game \& Fish Commissioner, Jefferson City, Missouri :

I am very glad indeed to note that the State of Missouri has in you a Game Warden that realizes the importance of the propagation, as well as the protection of our game birds, fish and animals. You are making a wise move in arranging for the propagation and distribution of Chinese Ring Necked Pheasants and English Pheasants. -And, by the way, there is no difference between the two birds. The ancestors of the English pheasants were imported from China to England some three hundred years ago. For the past three or four years, I have been reading up on the propagtion of the Chinese and English pheasants, and I find that the climate is well adapted for either. They are not only a handsome bird, but also a splendid table bird and very destructive to noxious insects and vermin, and therefore are great friends of the farmer. A year ago this month I purchased some Chinese Ring Necks of the Kendrick Pheasantry of Denver. I secured some five or six dozen eggs and hatched out some thirty or forty chicks, but I made a mistake in using game hens to hatch the birds, and before I got onto it, the hens killed the birds soon after hatching. I then switched to the common barnyard hens with more success. I, however, found that I did not have room enough in town, so sent them out to the farm and built a wire pheasantry, covering about threefourths of an acre, and succeeded in raising some birds. The farmers in the neighborhood are deeply interested in these birds, and the owners of about 2,000 acres of land have agreed to protect these birds against hunters, and supply feed for them during the winter. I am deeply interested in this move, and I am going to ask zou to send me as many pairs of Chinese Ring Necks as you can conscientiously spare, for the purpose of putting them out in the pheasantry, hatching the eggs under barnyard fowls and liberating the chicks on the 2,000 acres referred to. I believe that I can make a showing this fall that your office will be proud of, so kindly let me have as many as one-half dozen pair if possible.

I am having Mr. Bothwell, whom of course you know, to indorse me in this request.

Very truly yours,

(Signed) J. T. MONTGOMERY.

\section{IMPORTED BIRDS ARE PROTECTED.}

It is proper to state in this pamphlet, that the State laws of Missouri protect these birds, with which the Game and Fish Department is attempting to stock the. State, and that I will esteem it as a personal favor, as well as being an act of public benefit, if county officers, and private individuals also, will acquaint me with all facts connected with 
the violation of the laws, especially relating to the injuring, or attempted killing or injury of these birds which require such especial care and protection at this time, when there is no legal season for killing or capturing them.

\section{THE LAW UPON THE SUBJECT.}

Sec. 10. Game birds not to be killed.-Any person, who shall take, capture, or kill, except under permit, any woodcock, pinnated grouse (prairie chicken) ruffed grouse (pheasant), Mongolian, Chinese or English pheasant, or other resident or migratory or imported game bird, except as provided in section 9 , shall be punished by a fine of not less than $\$ 25.00$ nor more than $\$ 50.00$ for each offense, and additional fine of $\$ 5.00$ for each bird captured, killed or possessed.

Sec. 17. Not to have in possession-penalty.-Any person who shall have in his possession or under his control any variety of fish, game or birds during the close season prescribed by law therefor or any carcass or flesh thereof, except for scientific or propagating purposes, shall be punished by a fine not less than $\$ 50.00$, nor more than $\$ 100.00$.

Under section 51 of the State game and fish laws, no shipment of these birds is permitted except under permit, and with shipping tags showing such permit has been authorized by this office.

Very respectfully, etc.,

JESSE A. TOLERTON,

Jefferson City, Mo. 